\title{
O sentido do ser nos gregos antigos: uma análise heideggeriana
}

\section{The meaning of being in ancient greeks: a heideggerian analysis}

\author{
Maria Luísa Ramalho Ferreira da Silva ${ }^{1}$ \\ João Paulo Martins ${ }^{2}$ \\ Dilson Brito da Rocha 3
}

\section{Resumo}

Nosso objetivo neste estudo é investigar a maneira como Martin Heidegger, por meio de uma espécie de motu proprio, enfrenta a questão que gira em torno do sentido do ser nos gregos antigos, conditio sine qua non para que ele pudesse desenvolver seu suntuoso projeto filosófico. A fim de levar a cabo nosso propósito, examinaremos temáticas imprescindíveis nesta empreitada, centrando-nos nos pensadores primordiais que debruçaram sobre a physis, na filosofia platônica condizente ao tema, bem como na formulação aristotélica acerca da sabedoria teórica e da sabedoria prática e o sentido do ser.

Palavras-chave: Martin Heidegger. Sentido do ser. Pensadores primordiais.

Filosofia platônica. Formulação aristotélica.

\begin{abstract}
Our aim in this study is to investigate the way in which Martin Heidegger, through a kind of motu proprio, faces the question that revolves around the meaning of being in the ancient Greeks, conditio sine qua non so that he could develop his sumptuous philosophical project. In order to carry out our purpose, we will examine essential themes in this endeavor, focusing on the primordial thinkers who looked at physis, on the Platonic philosophy consistent with the theme, as well as on the Aristotelian formulation about theoretical wisdom and practical wisdom and the meaning of being.

Keywords: Martin Heidegger. Sense of being. Primordial thinkers. Platonic philosophy. Aristotelian formulation.

\footnotetext{
${ }^{1}$ Bacharel em Psicologia pela FIB - Faculdades Integradas de Bauru.

2 Professor na FIB - Faculdades Integradas de Bauru; Bacharel em Psicologia pela USC Universidade do Sagrado Coração; Mestre em Filosofia pela Universidade Estatual Paulista (UNESP/Marília).

3 Professor na FIB - Faculdades Integradas de Bauru; Mestre em Filosofia pela Universidade Estatual Paulista (UNESP/Marília); Mestre em Teologia pela Pontificia Università Gregoriana de Roma, Itália (PUG/Roma).

E-mail: dilsondarocha@hotmail.com
} 


\section{Os pensadores primordiais e o pensar e experimentar da physis}

A história acerca do sentido do ser não está constituída por posições filosóficas estanques reunidas em âmbito comum a partir do fato de todas tematizarem o ser ou tratarem dos mesmos problemas acerca desse. Todavia, tratase da história das sedimentações das determinações do ser do ente na totalidade que se confundem, tendo em vista o esquecimento do ser, com o percurso do conhecimento humano e seus diversos projetos históricos de mundo.

É o exercício de não considerar os indícios do mundo fático, nas quais Heidegger e sua obra estão inseridos, aquilo que permitiu que pensadores apresentassem narrativas a respeito dos filósofos primordiais tendo por base interpretações anacrônicas, sendo chamado por Heidegger de erro historiográfico. (cf. Ferreira, 2006, p. 36). Heidegger nos fala que "nós nos movimentamos constantemente em meio a campos de problematização sedimentados, oriundo de possibilidades abertas pelo passado" (CASANOVA, 2015, p. 82). Ora, isso quer dizer que o passado vige vigorosamente no presente e no futuro e, sendo assim, uma vez formulada uma questão (“o que é o ente?”) e uma vez constituídos os caminhos predominantes de resposta a ela (ontologia da presença), tudo cai em um espaço de obviedade.

Movimentando-nos dentro deste espaço de obviedade, retornamos aos pensadores primordiais, à experiência grega de physis, arché e alethéia. Ainda a partir da lida contemporânea técnico-científica tais termos podem ser contemplados em concepções distintas das quais serão aqui discorridas a fim de possibilitar a compreensão da visão de homem da fenomenologia, ou como já nos é permitido dizer, a noção de Ser-aí. Nesta o ente homem se encontra incessantemente articulado (cf. FERREIRA, 2006, p. 54).

Para Heidegger a história da filosofia ocidental nada mais é do que a história do esquecimento do ser. (cf. FERREIRA, 2006, p. 62). Não apenas devido ao erro historiográfico, mas, também, e essencialmente, devido ao traço fundamental do ser, traço esse que o levaria ao seu ocultamento na história da filosofia e no âmbito mais próximo e ordinário do ente homem, a saber: no cotidiano. Isso quer dizer que antes, tal esquecimento do ser, emerge enquanto uma dinâmica fundamental do ser, que se oculta mediante sua determinação em um ente. No entanto, o que se apresenta como um cenário ontológico próprio da constituição da metafísica 
ocidental, diz respeito a entificação do ser, ou seja, sua estratificação enquanto presentificado, que abre a possibilidade de se pensar em propriedades, faculdades ou atributos enquanto determinísticos do Ser-aí, ou em outras palavras, como nos é mais familiar, naturalístico, de natureza humana.

O pensador da fenomenologia hermenêutica percebeu que todas as ontologias ocidentais subsequentes a esse movimento de esquecimento do ser, que se sucedeu no âmbito da antiguidade grega, se encontravam sob o domínio dessa ontologia naturalística. Desta forma, desde seus primórdios nos gregos não puderam conquistar os seus próprios campos de investigação, se movimentando, já desde o princípio, a partir da conceptualidade grega de ente (cf. CASANOVA, 2015, p. 76).

Os pensadores primordiais elegeram a essência como physis, a filosofia socrático-platônica pode trazer à luz a noção de ideia e Aristóteles pode estabelecer a supremacia do primado teórico sobre o primado prático. O mundo medieval não consegue alcançar um caminho alternativo de reflexão 4 que não os paradigmas gregos de pensamento. $\mathrm{O}$ mundo moderno reduz a totalidade à dicotomia sujeitoobjeto e os contemporâneos se posicionam incessantemente dentro de modulações ontológicas metafísicas. Isso se deve a uma perspectiva que, em últimas consequências, carecem de uma lida destrutiva da ontologia grega, o que significa dizer que aponta desde o princípio para uma concepção legada dos gregos antigos e perpetuada até a contemporaneidade (cf. CASANOVA, 2015, 85).

A leitura heideggeriana da história do pensamento ocidental, tomado a partir de sua meditação acerca do esquecimento do ser, é visualizada como emergente de um acontecimento do ser no homem, ao que já mencionamos anteriormente como um caráter fundamental do Ser-aí. Como se dá essa dinâmica própria do ser? Como seria possível retomar o sentido do ser deixado de lado pela tradição? Heidegger revela que a resposta a tais questionamentos se encontra justamente nos pensadores primordiais, aqueles que originalmente pensaram o ser. (cf.

\footnotetext{
4 Heidegger, antes de chegar a compreender a ontologia grega como responsável pela articulação dos horizontes que possibilitaram o surgimento de todas as ontologias ocidentais posteriores, constata, ao olhar para o cristianismo primitivo e contrasta-lo com a experiência religiosa vigente na tradição escolástica, algo que foi decisivo para o rumo que sua obra tomou posteriormente. O filósofo contemplou que, na tentativa de fundamentar a experiência religiosa cristã, a mensagem cristã originária fora transformada por uma tentativa de buscar a verdade revelada nas escrituras, não a partir de uma lida destrutiva com a ontologia grega, mas, mais uma vez, a partir do modo mesmo de colocação da questão da verdade vigente no mundo grego, isto é, partindo da conceptualidade grega de mundo (cf. CASANOVA, 2015, p. 72).
} 
FERREIRA, 2006, 71). Para o filósofo alemão os pensadores primordiais foram contemporâneos ao nascimento mesmo da filosofia, portanto, não estariam tomados por uma linguagem conceitual que gerou e guiou toda a metafísica pósaristotélica, linguagem essa que colocou o ser no nível de conceitualização mais geral e indeterminado.

Para Heidegger o primeiro início do pensamento ocidental é um horizonte metafísico que se desvela com o pensamento pré-socrático e diz respeito à ambiguidade do acontecimento apropriativo, como acontecimento que se dá, antes, na própria dinâmica fundamental do ser. Recorrer ao termo physis nos possibilita tematizar esse primeiro início nos pré-socráticos. Porém, seu entendimento só se efetiva plenamente quando olhamos para a ruptura paradigmática que se dá entre o caráter originário do termo, nos pré-socráticos, e sua transformação em uma ontologia da presença a partir do pensamento posterior à filosofia socráticoplatônica (c. CABRAL, 2011, p. 37).

Physis do grego quer dizer natureza. Se faz necessário salientar que, a apreensão da palavra physis como natureza enquanto aquilo que está no âmbito físico, a partir de uma leitura científico-técnica de hoje, nos distancia totalmente de seu caráter fundamental e originário. Compreender tal termo como aquilo que é natural, isto é, físico ou substancial, apreensível de modo empírico, existente e perceptível à olho nu, portanto objetificável, nos coloca em uma interpretação que está ligada às tradições ulteriores ao pensamento dos gregos antigos, sobretudo, posterior à noção de physis entre os pré-socráticos. Sendo que a vigência inicial da physis não apenas se perde, mas é desfeita, ainda no desenvolvimento do pensamento grego antigo (cf. BRANCO, 2018, 34). Assim nos diz Heidegger:

Pois physis significa surgir emergente, que brota. O desabrochar e desprender-se que em si mesmo repousa. A partir de uma unidade originária se incluem e manifestam nesse vigor repouso e movimento. É a presença dominante, ainda não dominante ainda não dominada pelo pensamento. Nesse domínio, o presente se apresenta como ente. A vigência de um tal domínio só se instaura a partir do ocultamento. Isso significa para os gregos: aletheia (o desocultamento) se processa e acontece, quando o vigor se conquista a si mesmo como o mundo! Só através do mundo o ente se faz ente. (HEIDEGGER, 1999, p. 89, grifo nosso).

Nesta sentença o filósofo nos mostra o quanto sua leitura a respeito da physis pré-socrática está diretamente, e essencialmente, ligada ao constructo de aletheia, também grego (cf. CABRAL, 2011, p. 43). Nesse sentido, physis indica uma abertura 
dentro da qual o ente pode mostrar-se como tal, isto é, ela evoca o que se apresenta, o que se apresenta se faz presente, é presença e, portanto, é ente. Logo, physis possibilita a emergência do ente, mas não é um ente propriamente, pois na medida em que possibilita o desocultamento daquilo que brota e se faz presença ela não deixa desde o princípio de indicar, também, aquilo que se ausenta dentro de si mesma, aquilo que está em ocultamento. Em suma, physis indica uma unidade originária e comum que reúne, em si mesma, a dinâmica do que vem a ser e do que deixa de ser na mesma medida, além do próprio repouso do que permanece, se presenta (cf. BRANCO, 2018, p. 48).

O que chama atenção para a lida destrutiva da ontologia grega, é que, aqui o oculto não deixa de ser contemplado pelos filósofos pré-socráticos, conforme nos mostra, a própria noção de aletheia que, do grego, quer dizer verdade. Novamente, se faz necessário, a concepção desconstrutiva do termo. No horizonte de compreensão mais tradicional do termo, verdade é entendida como concordância entre um enunciado e o objeto ao qual se refere, como que uma apresentação de juízos corretos a respeito de um objeto, trata-se propriamente da excelência do discurso racional buscado pela metafísica e pela ciência, isto é, verdade enquanto uma sentença irrefutável. (cf. LOPARIC, 2015, p. 53).

A aletheia grega é por Heidegger compreendida como o próprio desocultamento, como uma mostração de todo e qualquer discurso dos entes em geral, não só sua mostração do discurso, mas a condição mesma de mostração que é possibilitada pelo mundo, considerado como o descerramento da totalidade do ente. (cf. CABRAL, 2011, p. 65). Para tanto, verdade não está desarticulada da noção de mundo, que por sua vez, não está desarticulado do ser, por isso o termo "Ser-aí" não pode ser esclarecido ou apreendido nas partes que o compõe, ser e aí. Portanto, Heidegger fala sobre a physis como um emergir (mostração), de forma a ligar simultaneamente esse emergir com um autoestabelecimento, uma presença, isso quer dizer que, ao mesmo tempo, a physis salvaguarda o lugar onde ela emergiu, esse lugar é o ocultamento (velamento). Ou seja, physis descreve o movimento de vir-a-ser e repousar em meio à sua aparição que dá ao ente a sua presença, de forma a preservar em si mesma a tensão inerente ao acontecimento do mundo, que descerra o campo de manifestação do ente na totalidade. Por isso Heidegger diz que “só através do mundo o ente se faz ente". (HEIDEGGER, 1999, p. 89). 
Ora, se para os gregos tanto a iluminação quanto a escuridão são manifestações que procedem da abertura franqueadora, a physis é, então, uma dinâmica de co-pertencimento original entre verdade e não-verdade, a própria aparência e o sombreamento das coisas são um modo de ser da permanência de tudo o que é e não é. Assim sendo, para os gregos antigos o que está em questão é o ser como physis, o que implica contemplar junto ao ser seu caráter de desvelamento e seu co-pertencimento ao ocultamento, ao ocultado (cf. BRANCO, 2018, p. 56).

Se assim for, a apreensão plena dos entes não pode ser efetivada, visto que o ser dos entes não é algo definível, delimitável ou apreensível, ou seja, os entes em geral não se podem fazer plenamente presentes em seu ser. Há sempre o velamento de aspectos e possibilidades na medida em que outros aspectos e possibilidades se fazem presentes no desocultamento. (cf. LYRA, 2006, p. 74). Ora, como dissemos, ao iniciar o leitor neste capítulo, junto ao erro historiográfico, que conduziu o pensamento ocidental ao esquecimento do ser, esteve a própria essência do ser que se oculta mediante sua determinação em um ente.

Assim, a história é por Heidegger abordada a partir da ideia de verdade, a verdade do ser, isto é, a ideia mesma de que o desvelamento dos entes é, essencialmente, a recusa original do ser a qualquer apreensão plena ou definitiva. Nesse sentido, nos diz Heidegger: “[...]o ser-aí nunca se encontra fora da filosofia, mas a própria filosofia pertence à essência da existência do ser-aí”. (HEIDEGGER, 2009, p. 11).

Os conhecimentos por nós conquistados até aqui, sobretudo, o de que o desnudamento do ente em sua plenitude constitui essencialmente uma impossibilidade, nos permite agora compreender como é possível que, para a fenomenologia heideggeriana, a simples e singela resposta para a pergunta "o que é o homem?" seja: "nada" 5 . Tal "nadidade" ontológica nos mostra que o ser do homem, sendo radicalmente pura intencionalidade, está fundamentalmente

\footnotetext{
5 Não se trata, contudo, de apreender o nada enquanto um objeto ou um ente, pois não é. O nada não acontece ao lado do ente ao qual o "aderiria", tão pouco o nada acontece para si mesmo. Mas nas palavras do próprio Heidegger (1999, p. 89) "O nada é a possibilidade da revelação do ente enquanto tal para o ser-aí humano”. Sendo assim, o nada não é um conceito nem distinto e nem oposto ao ente, mas sim o nada pertence originariamente à essência mesma do ser. Aqui e de agora em diante se faz necessário retomarmos o que vem sido contemplado ao longo deste capítulo, a noção mesmo de copertencimento, de "estar junto com" e não: "estar ao lado de". Assim sendo, nos mostra Heidegger, estar suspenso dentro do nada é o que quer dizer ser-aí, o que caracteriza, propriamente, sua dinâmica fundamental de ser pura intencionalidade, em seu caráter mesmo de abertura originária.
} 
marcado por uma ekstase $e^{6}$ originária, isto é, marcado por um movimento radical de exposição, o que nos leva ao termo ser-no-mundo, mundo sendo seu único apoio de realização (cf. CASANOVA, 2017, p. 79).

Se então, para os pensadores de origem, physis contempla o ser de tudo o que é e o que não é, de tudo que ao se desocultar se oculta, não indicando natureza enquanto parte unitária daquilo que se mostra como sendo a realidade ou verdade, como então poderia Heidegger conceber o lógos a partir de tal horizonte?

Heidegger nos diz que, em Platão e Aristóteles, lógos é polissêmico, o que faz com que os diversos significados possam se dispersar sem orientação de algum sentido fundamental. Sendo assim, lógos pode ter os seguintes significados: razão, pensamento, discurso e realidade conhecível, citados por Chauí. Também, como acrescenta Heidegger, pode significar: juízo, conceito, definição, fundamento, relação e proporção. Esses termos são próprios do horizonte metafísico da concepção de lógos, que de modo geral, nos remete ao ato de apreender e determinar algo. (cf. HEIDEGGER, 2015, p. 85).

No entanto, tais significados se caracterizam para Heidegger como aparências que se há de manter em lidas que não tomam para si a tarefa da lida destrutiva, que nos impede de tomar o sentido do termo em seu conteúdo primordial de significação básica. Sendo assim, para o filósofo, o significado básico de lógos é fala7. Fala aqui é tomada a partir de uma noção de: deixar ver a partir daquilo sobre o que fala, isto é, “[...] é aquela que retira o que diz daquilo sobre o que fala, de tal maneira que, em sua fala, a comunicação falada revele e, assim torne acessível aos outros, aquilo sobre o que fala” (HEIDEGGER, 2015, p. 72).

\footnotetext{
${ }^{6}$ Para Heidegger o ser do homem é marcado por uma ekstase originária, que se trata de um movimento radical de exposição, isto é, a dinâmica ekstática projeta o ser-aí para fora de toda e qualquer interioridade, o que quer dizer que o ser-aí nunca é primeiro dentro para depois se relacionar com o fora, já imediatamente esse se encontra fora. (cf. CASANOVA, 2017, p. 80). Nos diz Heidegger: "[...] o fato de que, por conta dessa sua essência, o homem é expelido para fora de si mesmo e para além de si, não sendo de maneira alguma uma propriedade de si mesmo", (HEIDEGGER, 2009, p. 12), isto é, o homem, enquanto um ente marcado por uma indeterminação ontológica originária, não pode ser determinado aprioristicamente e categoralmente. Assim sendo, como o ser do homem não se encontra previamente dado, não pode nunca encontrar "dentro" de si as orientações para os modos de ser, tais orientações estão no mundo, conforme já defendemos aqui, e, portanto, o ser do homem ao ter de ser já está desde o princípio lançado para fora. O que nos parece estranho, visto que a noção de dentro, de interioridade, de faculdades apriorísticas nos foi vastamente apresentada pela tradição encurtada. E é neste sentido que o termo ekstase se justifica. 7 Tal termo é empregado por Heidegger no sentido da palavra alemã legen que quer dizer de-por (no sentido de estender e prostrar) e propor (no sentido de adiantar e apresentar). (cf. BRANCO, 2018, p. 97). Nesse sentido, fala se dá aqui como um colher, recolher, escolher, apanhar e juntar. Isto é, se compreende falar por de-por (prostrar) e propor (deixar disponível em um conjunto) o que é desvelado, em outras palavras, trata-se de pôr uma coisa junto com outra.
} 
O que essa citação direta, aparentemente confusa, nos mostra? Ora, nos revela simplesmente uma noção que articula lógos, fala, physis e alethéia. Até mesmo, porque, a conceituação e definição do fenômeno, seja ele qual for, em categorias ou em partes substancializadas de um todo, é uma característica da filosofia aristotélica em diante, aqui (entre os pensadores primordiais) tal distinção não possui sentido algum. Sendo assim, os termos possuem uma relação muito mais viva entre si, do que uma simples divisão de funções que constroem a realidade do mundo. O que seria propriamente "aquilo sobre o que a fala diz", senão aquilo mesmo que se desvela, no sentido grego da palavra alethéia, aquilo que se desoculta. O desocultamento (alethéia) do ente a partir da unidade franqueadora (physis) que, não deixa de salvaguardar, ao mesmo tempo, o lugar de onde o ente emergiu, isto é, o ocultamento.

O lógos, por deixar e fazer ver algo como algo, isto é, o ente como algo desvelado, pode ser compreendido como o elemento que unifica e reúne a aparição dos entes. Porém, não como uma ferramenta subjetiva determinante que permite acesso ao ente a partir da physis, ao contrário, o lógos indica um deixar ser manifestativo, um tornar acessível o que é desvelado, sem deixar de salvaguardar o que subjaz a todos os entes, o que se oculta (cf. BRANCO, 2018, p. 98).

A partir de tal horizonte podemos contemplar o lógos como pensar. A própria dinâmica do ser consiste em ocultar-se frente sua determinação num ente. Assim sendo, o ente homem pensa justamente porque o seu fundamento originário, o ser, se oculta. É a constância do desocultamento que propicia o pensar, um abrir-se ou um iluminar-se a partir da evidência mesma do ser. Portanto, é através do próprio pensar do ser que esse se determina num ente, pois vem à tona através do ente, em outras palavras: se deixa ver, é fala, é linguagem. Trata-se de uma retirada que se mostra abrindo o ente e realça que o ausente tem vigência maior do que a força mesmo da presença. O pensar originário no primeiro princípio (physis), portanto, nada mais é do que o pensar do ser se revelando, isto é, o pensar é fruto da manifestação elementar (cf. BRANCO, 2018, p. 102).

A fim de tomar a noção de aletheia a partir de outro ponto de apoio para expressar a lida heideggeriana deste termo, consideremos o rapsodo Homero e uma passagem de sua obra Ilíada, o qual se situa historiograficamente em um período anterior ao dos pré-socráticos, mas ainda assim se encontra junto aos mesmos no sentido de que tanto Homero quanto os pré-socráticos vivenciaram o ente 
originalmente e não estiveram contaminados com a linguagem metafísica acerca da questão do ente, uma vez que antecede a vigência desta mesma. Bem como, consideremos brevemente e de modo geral a narrativa mítica para nos auxiliar a compreender como se dá a retomada do fenomenólogo aos pensadores primordiais ${ }^{8}$.

O poeta Homero canta os entes da seguinte forma:

De novo levantou-se Calcas, o Testórida, o mais sábio dos augúres. Que conhecia o que é, o que será e o que foi antes. Que conduzira até ante Tróia os navios dos aqueus. Com o espírito profético com que honrara Febo Apolo. (HOMERO apUd FERREIRA, 2006, p. 5).

Chauí nos apresenta uma narrativa a respeito do período que antecedeu o surgimento da figura do filósofo. Para ela, o Mestre da Verdade fora a figura que precedera o filósofo. O Mestre da Verdade seria aquele que: como poeta vê o passado e como adivinho vê o futuro. O que vê o poeta e o que adivinha o mago. Nesse sentido, a palavra a-létheia é uma palavra que se diz negativamente, já que o prefixo a- indica negação. Sendo léthe esquecimento ou esquecido, aletheia seria: não esquecimento, não esquecido. Na narrativa mítica aletheia possuiria uma relação intrínseca com os procedimentos oraculares e divinatórios:

O oráculo (Musas, Apolo) desce ao Hades (reino dos mortos) e ali vê a verdade; o interrogante (poeta, adivinho, rei de justiça) aproxima-se do oráculo para pedir-lhe que diga a verdade vista e lhe permita ver também. Para aproximar-se do oráculo, o interrogante deve passar por duas fontes vizinhas: Léthe (água do esquecimento) e Mnemosyne (água da memória). Se beber a água da primeira, esquecerá de tudo o que ouviu e viu; se beber a da segunda, nada esquecerá e tudo lembrará. O não esquecimento ou a lembrança do que foi contemplado e ouvido é a verdade, alétheia (CHAUÎ, 2002, p. 41, grifo da autora).

Portanto, nos conta o mito que, o Mestre da Verdade é capaz de ver o invisível ou o oculto e, sendo assim, sua palavra é eficaz porque quando o poeta canta, o passado se faz presente e quando o mago anuncia, o futuro se faz presente (cf. CHAUÍ, 2002, p. 43). Como poderia tais considerações, aparentemente,

\footnotetext{
${ }^{8}$ O filósofo Pierre Hadot, que tem uma vasta obra na qual se ocupa da filosofia helênica, propõe uma interpretação de que os primeiros pensadores, ao substituir a narração mítica por uma narração lógica (e isto indica a conhecida passagem histórica entre a cosmogonia e a cosmologia, comumente entendida como o nascimento da filosofia), conservaram o esquema que estruturava as cosmogonias místicas. A transposição mesma da narração mística para uma teoria racional - teoria racional, pois procura explicar o mundo não mais pela luta entre elementos, mas pela luta entre realidades "naturais" -. O objeto que elegerem para investigação foi a physis. Sendo assim, para tal autor, toda a tradição filosófica grega em seu princípio e posterioridade é influenciada por esse esquema cosmogônico original (cf. HADOT, 2014, p. 64).
} 
sobrenaturais e místicas estarem relacionadas à verdade do ser? Para Heidegger, Homero ao falar do "que é", do "que foi" e do "que será" nomeia o ente, o nomeia relacionando-o ao presente, ao passado e ao futuro. A questão não é compreender passado, presente e futuro como espaços temporais, substanciais e distintos, conforme a concepção moderna. Trata-se de compreender passado, presente e futuro como um modo especial de presença. Então, Homero ao fazer o vidente falar mostra o ente como representante de tudo o que se presenta na presença e na ausência, isto sendo, passado e futuro estando na ausência são modos distintos do ente se presentar.

Em outras palavras o oculto é considerado como co-pertencente do desvelado. $O$ vidente pode falar (deixar ver aquilo do que se fala) tendo em vista que sua percepção não está atrelada ao caráter estático do que presentemente se presenta, ou seja, do ente determinado. Ora, se o vidente não partir da noção estática da essência do ser, se não considerar o ente determinado como o ser puro, absoluto e necessário pode, então, alcançar o que se presenta na ausência, ou seja, o que se encontra velado face ao que está desvelado (cf. FERREIRA, 2006, p. 87).

O que se torna fulcral nesse retorno aos filósofos pré-socráticos, tarefa essa que, segundo Heidegger, é primordial em uma lida destrutiva da ontologia grega, é que os filósofos da physis não promoveram e não tinham por intento a divisão de uma realidade em dois polos dualísticos. Tal como filósofos puderam supor e interpretar, isto a partir de uma lida própria da metafísica. Esta dicotomização nos é muito familiar e constitui a forma mesma como sempre colocamos a questão do sentido do ser. Polos opostos e distintos um do outro, no qual costumamos nos movimentar ao interpretar o ente homem. Polos distintos como real e transcendente e imanente, verdadeiro e aparente, eterno e temporal. Nas palavras de Branco: "tanto as sombras como a iluminação do Sol são modos e manifestações de uma realidade ímpar e original, já que procedem da própria physis, abertura franqueadora de toda realização e desrealização de toda ordem e desordem". (BRANCO, 2018, p. 17).

Sendo assim, na noção pré-socrática de physis e de aletheia, bem como, na própria dinâmica fundamental do ser, o que se presenta (desvela) não está separado do que se ausenta (vela) como partes distintas em si mesmas, mas, antes, fazem parte de um polo correlato de vigência. A época seguinte aos filósofos pré-socráticos possibilita a emersão do pensamento platônico, a partir do qual a aletheia passa a 
ser entendida como que um objeto (e agora a possibilidade de objetividade e objeto de conhecimento passa a surgir como um horizonte de possibilidade) de desejo da filosofia, em que a busca se dá como que uma forma de dominar a verdade, isto é, a, incessante, e ainda atual, busca por apreende-la em sua constituição plena e pura.

É contudo, o esquecimento do ser, isto é, a partir do momento em que o ente passa a ser concebido sem a clara remissão ao jogo ontológico entre o desvelamento e o velamento do ser, que se dá a abertura da possibilidade da metafísica. (cf. CABRAL, 2011, p. 56). Ou em outras palavras: a própria dinâmica da physis nos permite entrever o porquê do desenvolvimento da metafísica como marca predominante, e até essencial, dos mundos epocais que compõem a história do Ocidente.

Ente é pensado e vivenciado pelos filósofos primordiais como representante da multiplicidade do que se presenta e se ausenta e, por isso, o ente é a totalidade das coisas, isto é, totalidade das coisas que presentemente se presentam e se ausentam. Multiplicidade esta que se encontra reunida na dinâmica mesma do ser, nesse sentido, o ente se movimenta em torno do ser que se vela e desvela segundo a ordem do tempo (caráter epocal do ser, isto é, tempo como aí). Por isso, ser humano é a-ser, a ser exercido, a ser exercido a cada vez. Ser humano é propriamente um aser-o-aí (cf. LOPARIC, 2015, p. 78).

Para Nietzsche com o triunfo do niilismo 9 a vontade de potência deixa de significar "criar" para querer dizer "dominar". (cf. FEREZ, 1996, p. 95). Os verbos “criar" e "dominar" sintetizam, partindo de uma leitura nietzschiana, a mudança de paradigma que marca essencialmente o nascimento da filosofia e o início propriamente da história do pensamento ocidental, mudança essa que está na tentativa de explanação que se discorre de agora em diante.

\footnotetext{
9 Niilismo entende-se como o abandono do ser, chamado até aqui de esquecimento do ser, ainda que esquecimento do ser queira dizer mais propriamente a respeito da formulação da questão do sentido do ser no interior do pensamento metafísico ocidental. Nas palavras de Heidegger: "O abandono do ser em relação ao ente é o fundamento mais velado e mais próprio daquilo que Nietzsche reconheceu pela primeira vez como 'niilismo' e concebeu a partir da 'moral', do 'ideal', de maneira platônicaschopenhaueriana, mas ainda não metafisicamente.”. (HEIDEGGER apud CASANOVA (2012, p. 189).
} 


\section{A transmutação ontológica: o revelar da noção de ideia da filosofia platônica}

O retorno aos pensadores primordiais nos possibilitou contemplar que a vigência do ser (presença) indica tanto a presença, isto é, o ente propriamente, quanto o ser que se retrai em velamento, abarcando, assim, tanto a manifestação em desvelamento, quanto o próprio estado de velamento. Já que ambos são correlatos e não existem em distinção um ao outro. Nesse sentido, physis é concebida como um modo e uma maneira de ganhar presença, isto é, ser é o próprio presentar-se dos entes. Algo de primordial se destaca nesta perspectiva, a saber, é a própria noção de mobilidade, visto que os entes, que são a partir da physis, o são em mobilidade. Isto é, para os pensadores primordiais, "[...] a $\varphi v \dot{\sigma \iota s}$ [physis] é compreendida como ponto de partida da mobilidade do movido a partir de si mesmo, sendo que o movido retorna a si". (BRANCO, 2018, p. 27). O que nos aponta que a mobilidade não é considerada, aqui, como coisa distinta do ente desvelado que move mecanicamente os entes, sendo assim sua causa primeira, mas mobilidade é o próprio desvelar-velando.

Essa noção de que a mobilidade não é a causa eficiente dos entes nos permite, mais uma vez, retornar à formulação heideggeriana de nadidade ontológica. Pois, nos coloca mais uma vez a questão de que o desvelamento do ente em sua plenitude é, essencialmente, uma impossibilidade. O que Nietzsche ${ }^{10}$, em comum com Heráclito, segundo Störig, narrariam como a forma mesma como o mundo aparece, ou seja, o mundo aparece como um processo infinito do vir-a-ser e perecer, do criar e do destruir e, portanto, mundo seria um eterno-criar-a-si-próprio e um eternodestruir-a-si-próprio, isto é, transformando-se eternamente. (cf. STÖRIG (2009, p. 53). Esta concepção de mobilidade se opõe, essencialmente, a noção de imutabilidade, própria da ontologia metafísica, que busca, sobretudo, a apreensão dos princípios puros e absolutos de constituição do ser, nesta perspectiva, apenas

\footnotetext{
${ }^{10}$ Ainda que não seja nosso propósito nos determos às consonâncias e desencontros entre Nietzsche e Heidegger revela-se aqui que a filosofia nietzscheana é compreendida, pelo pensador da fenomenologia hermenêutica, como a consumação mesma do próprio niilismo (cf. CASANOVA, 2012, p. 45). Tal assunto é discorrido com precisão pelos filósofos brasileiros o Prof. Dr. Marco Antônio Casanova em seu texto "O homem entediado: niilismo e técnica no pensamento de Martin Heidegger" e o Prof. Dr. Alexandre Marques Cabral em sua tese de doutorado em filosofia chamada "Niilismo e hierofania: uma abordagem a partir do confronto entre Nietzsche e Heidegger". Para tornar esclarecido, Nietzsche será considerado neste texto como um pensador que ao retornar aos pré-socráticos, assim como Heiddegger, pode vislumbrar o surgimento da metafísica no interior do pensamento socrático-platônico.
} 
esses princípios seriam considerados de primeira ordem, ou seja, seriam a causa de si mesmo e de todas as outras coisas, portanto, imutáveis.

Sendo assim, Branco nos mostra que o ocultamento da physis no seu caráter de sombreamento só fora marginalizado mais tarde na filosofia platônica. Platão, que ao formular sua noção de ideia, assim fez rebaixando o caráter de ocultamento da physis à aparência do real (ideia), de forma a estabelecer como principal tarefa da filosofia a busca pelo real em contrapartida ao que por ser aparente nos distancia do real. (cf. BRANCO, 2018, p. 79). Ou seja, é por excluir da noção de ser o caráter de ocultamento, que Platão pode compreender o ser como presença constante.

É o próprio esquecimento do ser, que exalta, a partir de Platão ${ }^{11}$, a possibilidade de uma pretensão da filosofia e, posteriormente, da própria ciência de apreender e dominar aquilo que é a priori, isto é, tentar apreender o necessário e absoluto que, em tese, se daria anterior à qualquer manifestação do ente. É por esquecer o que apresentou Heráclito de Éfeso, citado por Branco na frase: "o ser ama esconder-se”. (BRANCO, 2018, p. 30). É, então, por deixar de considerar o esconder-se como o pertencer essencial e originário ao ser, para então, buscar apreender e dominar o ser em sua plenitude. E é nesse sentido que Nietzsche apontou para o triunfo do niilismo como a transformação do significado de vontade de poder ${ }^{12}$, que passa a querer dizer "dominar", ou seja, assume-se, assim, que a apreensão plena do ser constitui uma possibilidade da qual o ente homem é dotado de capacidade para alcançar. Isso, pois, se mundo deixa de ser considerado um eterno processo de vir-a-ser e perecer, de criar e destruir, é que a busca por aquilo

\footnotetext{
${ }^{11}$ Essa expressão "a partir de Platão" não indica, nesta pesquisa, uma abordagem causal que atribui à esta personalidade em específico como a única, ou mesmo como a principal, determinante para os acontecimentos discorridos a seu respeito. Tal consideração constituiria uma contradição mesma diante do método da hermenêutica da facticidade. Segundo Casanova, para Heidegger, Platão e Aristóteles são decisivos para a constituição das estruturas prévias de nossa interpretação dos entes, estruturas que sedimentadas ao longo dos tempos possibilitam que nos movimentemos sempre e mais uma vez em horizontes investigativos. Portanto, não se desconsidera aqui o próprio mundo fático no qual os nomes Platão e Aristóteles se desvelaram e tornaram vigentes, tal como já se encontra implícita na própria interpretação hermenêutica heideggeriana da ontologia grega e da metafísica adiante, a mesma adotada como método de investigação desta monografia.

${ }_{12}$ Tendo em vista que todo pensamento nietzschiano está articulado a partir de um embate crítico com a tradição filosófica, vontade de poder responde a um horizonte hermenêutico e é concebido por Nietzsche como princípio de constituição do mundo. No entanto, aqui o real deve ser compreendido como resultado de um modo de estruturação de uma pluralidade de elementos relacionados entre si. Sendo assim, vontade de poder é aquilo que rege a realidade, não como essência ou substância, mas como o que insiste em retornar para um se constituir (cf. CABRAL, 2009, p. 67).
} 
que permaneça, que seja estático ${ }^{13}$, se torna uma possibilidade e tarefa de realização da própria filosofia.

No livro III de Crepúsculo dos Ídolos, intitulado "A 'razão' na filosofia", Nietzsche exemplifica e discorre a respeito deste fenômeno que chamou de "idiossincrasia" nos filósofos:

[...] sua falta de sentido histórico, seu ódio à noção mesma do vir-a-ser, seu egipcismo [tendência de permanência estática, segundo nota do tradutor]. Eles acreditam fazer uma honra a uma coisa quando a des-historicizam, sub specie aeterni [sob a perspectiva de eternidade], quando fazem dela uma múmia. Tudo o que os filósofos manejaram, por milênios, foram conceitos-múmias; nada realmente vivo saiu de suas mãos. Eles matam, eles empalham quando adoram, esses idólatras de conceitos [...] A morte, a mudança, a idade, assim como a procriação e o crescimento, são para eles objeções - até mesmo refutações (NIETZSCHE, 2006, p. 25).

O que Nietzsche nos aponta no imperativo supracitado é justamente a mudança paradigmática que ocorreu entre os pensadores da physis, os présocráticos, e os pensadores posteriores, período comumente chamado de socrático ou antropológico ${ }^{14}$. Sendo assim, o que se manifesta em tal sentença indica a própria ambição dos filósofos deste período em encontrar princípios que fossem universais e absolutos, que, de modo geral, não estariam passíveis à erro ou ao engano e que se constituiria como real e verdadeiro. Traria-se de egipcismo em uma perspectiva de eternidade, conforme expressa o filósofo alemão.

A tese socrático-platônica que compõem o núcleo de sua concepção de conhecimento é a teoria da reminiscência que, segundo Chauí, consiste em uma afirmação de que conhecer é reconhecer ou recordar a verdade que se encontra adormecida em nossa alma racional. Isso implica dizer que a essência da alma é a razão, alma é essencialmente racional, por isso, pode conhecer a verdade. (cf. CHAUÍ, 2002, p. 65). Logo, emerge a noção de que no interior do espírito do homem se encontra a verdade adormecida. Verdade perde seu caráter de mobilidade, de

\footnotetext{
${ }^{13}$ Segundo Heidegger, temos a impressão de que o homem e o mundo possuem características essencialmente estáticas, ou seja, que ambos já são definidos e determinados por aspectos e propriedades essenciais e eternamente imutáveis, devido ao fato de que não conseguimos visualizar o ser por ele mesmo, pois o ser só se apresenta a nós objetivado no ente. Essa tendência do ser-aí de esquecer o ser do ente que ele é possibilita o caráter estático que, por sua vez, é possível também articulado à essência epocal do ser. (cf. FERREIRA, 2006, p. 46).

$14 \mathrm{~A}$ seguinte divisão de períodos está sendo feita para fins de facilitar a expressão das noções aqui apresentadas, no entanto, se faz necessário ressaltar que tanto Heidegger como o Nietzsche apontam que ainda no período pré-socrático noções como estaticidade e imutabilidade dos entes já eram discorridas entre alguns dos pensadores da physis, como, por exemplo, o eleata Parmênides.
} 
mutabilidade, contudo, a verdade aqui passa a ser contemplada como presença que não perece, mas é eternamente enquanto ideia.

É justamente a esse pensamento que Nietzsche se opõem. Isto é, se opõe a esta filosofia que, além de colocar a verdade como eternamente imutável, a coloca acessível através da racionalidade, razão que apreende o absoluto e imutável. Como poderia a razão apreender os princípios puros e imutáveis? Ora, nos diz o filósofo alemão, por meio da completa negação da força dos impulsos, aquilo que Platão chamou de sentidos ou mundo das aparências. Isso, pois, a razão seria nesta perspectiva compreendida como atividade inteiramente livre, isto é, pura e desprovida de historicidade, de transformação, de vir-a-ser, aspectos próprios do mundo que Platão chamou de mundo das aparências.

Ora, somente baseado na tendência à uma permanência estática sob uma perspectiva de eternidade é que poderia a filosofia abandonar o ser do ente, ou seja, abandonar o sentido originário de verdade, enquanto aletheia que, em sua consideração mais fundamental, indica tudo aquilo que ao se desocultar se oculta na mesma medida. Conforme as palavras de Nietzsche "agora todos eles crêem, com desespero até, no ser. Mas, como dele não se apoderam, buscam os motivos pelos quais lhes é negado. 'Deve haver uma aparência, um engano, que nos impede de perceber o ser [...]” (NIETZSCHE, 2006, p. 25). Essa aparência constitui a tais pensadores como o próprio obstáculo de se atingir a verdade imutável. Já foi discorrido neste capítulo que a apreensão plena dos entes não pode ser efetivada, visto que o ser dos entes não é algo apreensível, uma vez que o desocultamento de possibilidades e aspectos implica sempre no velamento de outras possibilidades e aspectos. Os entes em geral não podem fazer-se plenamente presentes em seu ser.

O que Nietzsche nos diz ao falar que "eles" criam no ser, é expressado por Branco que nos diz que o platonismo até experimentou a essência da verdade no sentido da aletheia, ou seja, a questão originariamente pensada pelos filósofos da physis. (cf. BRANCO, 2018, p. 96). No entanto, de modo próprio, Platão procurou atingir a essência que subjaz ao desvelamento da aletheia, o que o distanciou dos gregos anteriores. Ao buscar atingir tal essência primeira, o platonismo nomeou aquilo que dá préstimo a tudo, que dá visibilidade ao desocultado, de ideia.

Trata-se de uma virada da noção de aletheia, uma vez que o traço fundamental dessa passa a ser no interior do pensamento platônico a ideia. Assim sendo, a filosofia platônica contempla a ideia como promotora do ser dos entes, ou 
seja, se a ideia subjaz e constitui o traço fundamental dos entes das coisas, é justamente sob a luz das ideias que o homem pode ver o real corretamente. Nesse sentido, aquilo que apreendemos sensivelmente, isto é, as coisas que são visíveis, audíveis, táteis, olfativas, calculáveis são imagens do real, são aparências das ideias. Aqui se dissolve a noção de que a physis seja o ponto de partida e de retorno da mobilidade do movido a partir de si mesmo, aqui a mobilidade daquilo que é movido não é o que é movido propriamente, mas é a ideia. Assim, na teoria platônica de verdade, o desvelado é concebido de antemão como aquilo que é apreendido na apreensão da ideia, esta é a noção mesma de que as coisas são antes de serem, isso quer dizer que aqui a noção de a priori, tal como nos é tradicionalmente conhecido, eclode. (cf. BRANCO, 2018, p. 78).

Ora, se antes do desvelar do ser do ente, este ser já é compreendido como existente de antemão, então, se torna possível contemplar o tal mundo das ideias como a causa primeira e, assim, imutável e eterno. Isso, pois, antes de ser já é, já é em essência como uma ideia. Tal horizonte permitiu algo como uma pretensão de arrancar a realidade de seu velamento, pois a realidade aqui não é vista mais como algo se desvela-velando, conforme concebido pelos pensadores primordiais. Mais uma vez, se torna evidente os termos utilizados por Nietzsche, uma vez que mundo deixa de querer dizer "criar", no sentido de contemplar o processo eterno de vir-aser e perecer, para querer dizer "dominar", no sentido de buscar apreender o que subjaz a todas as coisas enquanto causa primeira. Assim, e só assim, é que o ser poderia ser definível, apreensível e dominável.

O meio mesmo pelo qual é possível a apreensão do real corretamente é a alma racional. Para Platão, a alma racional nada mais é do que uma natureza intermediária entre o divino mundo das ideias e o mundo sensível, e compõe com o corpo o ente chamado homem. Em suma, alma ( $p s i k h e ́$ ) é concebida pela filosofia platônica como princípio vital que anima um ser, isto é, que lhe dá vida. Alma é compreendida como o princípio da autoatividade e autoconservação do cosmo. Ora, agora que o ente pode ser considerado como algo dotado de uma identidade, isto é, dotado de algo como uma essência que subjaz antes mesmo de seu desvelamento, é que o ente homem pode ser pensado como aquele que possui alma racional enquanto propriedade. Nesse sentido, o ente passa a ser determinado como um objeto que está à mercê da atividade mais própria da alma, a saber o pensar racional. (cf. CHAUí, 2002, p. 68). 
Agora sim, a partir do platonismo, é que a noção de lógos enquanto pensamento racional, ou enquanto razão propriamente, pode ser tomado em consideração, de forma a perder o sentido originário que, a recordar, é o deixar e fazer ver manifestativo de algo enquanto algo. Partindo de tal modo de pensar é que lógos pode ter o sentido de uma ferramenta subjetiva que permite acesso ao ente a partir da physis. O que se torna evidente é que a unidade eclosiva da physis deixa de ter em si mesma a solidez e a força que teve no seu revelar originário nos pensadores primordiais. Outrossim, deixa de indicar a unidade originária e comum que reúne, em si mesma, a dinâmica do que desvela-velando, perdendo espaço para a alma racional, compreendida na filosofia platônica como via de acesso à ideia, essa sim, vista como causa primeira do ser dos entes.

$\mathrm{E}$ a aletheia, por fim, perde seu sentido fundamental de co-pertencimento entre o velar e o desvelar, que contempla, sobretudo, a vigência do ausente nas manifestações dos entes e que indica, em suma, a manifestação constante e inesgotável do próprio ser, para ser considerada, conforme Chauí nos diz, como ação última e absoluta da alma que possui evidência. Possui evidência, uma vez que elimina toda e qualquer menção ao que está oculto. Verdade é evidência pois é visível sem sombras e obscuridades. Sendo assim, verdade pode ser considerada como um juízo que é correto por ser irrefutável.

Os filósofos em seu anseio pelo princípio eterno e imutável viram o mundo empírico como um mundo de engano. Concluíram, portanto, que do mundo empírico não poderia proceder a verdade (enquanto princípio absoluto), o mundo das aparências contradiz essencialmente tal verdade. E na Índia e na Grécia o erro do ser foi cometido: "Devemos já ter habitado um mundo mais elevado ( - em vez de um bem mais baixo: o que teria sido a verdade!), devemos ter sido divinos, pois temos a razão!" (NIETZSCHE, 2006, p. 28). Nesse sentido, para a filosofia, o sábio se constitui o homem que, por ter razão, possui uma intuição imutável, impessoal e universal, capaz, por ser racional, de atingir o conhecimento imutável. Desta maneira, a verdade se constitui na adequação entre as coisas e o intelecto, o homem e as coisas. (cf. NIETZSCHE, 2001, p. 32).

Com a apresentação de tal interpretação realizada pelo filósofo alemão é que se pode contemplar a forma mesmo como a transcendência é, neste horizonte, compreendida. Conforme Cabral, a palavra transcendência é oriunda do termo latino trans-acendere e tem como significado originário "subir além de...", "subir 
para além de...” ou "ir para além de...”. Não se trata, a princípio, de um atributo de um ente determinado, ou seja, originariamente o significado de transcendência não é expressado como se fosse uma propriedade interna de um ente específico, o homem. Antes de tal noção, transcendência caracteriza mais uma espécie de um movimento intencional, pelo qual o homem ultrapassa os limites de sua situação no mundo e na história, se lançando em uma realidade transmundana e transistórica. Essa experiência entre os gregos antigos é pensada como a própria noção de ideia.

Essa experiência de absoluto, para Cabral, constituiria uma espécie de "excesso ontológico", a partir do qual o homem se desvincula de seus laços mundanos e históricos para assegurar que há um princípio fornecedor de medidas gerados de diversos símbolos, tais como religiões, moral, política e outros. Ora, isso nos auxilia na compreensão da própria intenção da filosofia platônica-aristotélica de atingir o ente absoluto que preexiste à própria relação intencional, isto é, que por ser de primeira ordem é a causa de si mesmo e de todas as coisas. Por isso, o absoluto poderia fornecer critérios seguros para uma crítica efetiva de todos os "falsos absolutos" que funcionam como aparências. Este ente suprassensível ente supremo que é causa primeira de todos os entes é pensado como Deus ${ }^{15}$. Deus, o ente suprassensível, que é causa primeira de si e de todos os entes. (HEIDEGGER, 2005, p. 56).

\section{A formulação aristotélica de sabedoria teórica e sabedoria prática e o sentido do ser}

Para Heidegger, tanto Platão quanto Aristóteles foram decisivos para a constituição das estruturas prévias de nossa interpretação dos entes, neles se encontra a origem de boa parte de horizontes interpretativos posteriormente sedimentados, horizontes os quais nos movimentamos ainda. Heidegger, em sua leitura dos pensadores gregos antigos, não compreende tais formulações como um longo inventário rigoroso dos modos de ser dos entes e de categorias que os subjazem. O que está em jogo propriamente é o problema da unidade do ser, isto é, um radical questionamento acerca do ser uno. Este nada mais é do que aquele ser

${ }^{15}$ Tais formulações apresentadas aqui antecedem o surgimento mesmo do cristianismo enquanto paradigma, portanto, ressalta-se que Deus não é formulado aqui como o Deus cristão tal como um sistema teo-ontológico emergira em períodos ulteriores. 
uno que fora pensado como aquele que atravessa todo e qualquer campo de constituição dos entes em geral, em suma, o que anteriormente denominamos Deus (cf. CASANOVA, 2015, p. 47).

O termo Deus ou o ser uno dos entes em geral nos aponta para uma formulação de uma ontologia da presença constante, ou seja, o ser fora pensado, a partir da filosofia platônica-aristotélica, como permanência, sempre vigente, vigente como um vigor que reina antes de tudo antes de qualquer manifestação, antes que qualquer ente. Só a partir de tal concepção, é que a busca por uma ontologia de base, isto é, uma ontologia pura que anteceda e determine os entes em geral pode ser levada em consideração. É a este horizonte que Heidegger se refere como sendo o estruturante de toda posterior forma de colocação do sentido do ser no interior do pensamento ocidental (cf. BRANCO, 2018, p. 107).

Aristóteles e Platão condensaram na palavra “ousía” a noção mesma do ser enquanto permanência. O termo é designado, a princípio, como fazendo menção à dimensão do ser que perdura por mais de um instante, que possui duração. Se encontra associado a um tempo mítico e, em suma, indicou o caráter supratemporal do mito. Mais tarde fora traduzido pelos romanos como substantia, traduzido, no entanto, de forma a desconsiderar a experiência temporal que possibilitou seu sentido originário. E a relação entre ser e tempo se encontra velada a partir da filosofia platônica-aristotélica que enaltece, portanto, a concepção de ser enquanto ousía, substantia, ou presença constante, ser enquanto aquilo que permanece para além das transformações do mundo fenomênico (cf. CASANOVA, 2015, p. 64).

Para Heidegger, Aristóteles e Platão, estabeleceram pela primeira vez uma distinção entre a filosofia as outras ciências em geral. A filosofia seria encarregada pelo desenvolvimento do conhecimento puro e a priori, constituindo-se, assim, como a ciência do ser enquanto ser. Em sua contraposição estariam as outras ciências ônticas que se caracterizariam por seu conhecimento empírico e $a$ posteriori, sendo assim designado a voltar-se ao domínio específico de leis e de princípios reguladores de um campo de objetos positivamente instituídos. Como nos mostra Casanova, Aristóteles chamou de sabedoria prática aquele saber que depende da ação para produzir o que ela se destina, sendo, portanto regida para algum fim, e denominou sabedoria teórica aquela que é realizada com vistas a ela mesma, isto é, não possui nenhum outro fim externo a si própria para concretizar sua significação mais própria. 
O que se apresenta com a formulação aristotélica acerca do homem vai além da suposição, anteriormente formulada e defendida por Platão. Isto é, de que verdade diria respeito, exclusivamente, a um conjunto de proposições que revelariam um conteúdo específico oriundo de entidades supra-sensíveis. Também que poderiam ser estabelecidas para além de qualquer comportamento específico dos homens. Em outras palavras, Platão viu no mundo empírico um erro, erro que distanciava consideravelmente do que seria mais real e bom, o mundo das ideias. $\mathrm{O}$ que se revela em Aristóteles é uma abrangência da concepção platônica, a saber, a compreensão de que tanto o primado da sabedoria teórica quanto o primado da sabedoria prática repousariam sobre possibilidades do ser do homem, ambos como modos específicos de ser do homem. No entanto, essas possibilidades não se equivalem por completo (cf. CASANOVA, 2015, 78).

Se para Platão há uma generalização do aspecto que promove presença aos entes, a lembrar, a ideia, para Aristóteles há uma valorização do composto entre matéria e forma. Isso quer dizer que em Platão a dimensão corpórea indica necessariamente o não-ser, uma mera aparência e em Aristóteles há a proximidade entre matéria e forma. No pensamento metafísico de Aristóteles a matéria e forma são partes essenciais da physis, no entanto, forma tem primazia sobre a matéria. Isto, pois, nesta concepção um ente só é propriamente um ente quando está sob o modo de ato finalizado, tendo cumprido o seu télos (finalidade). Por exemplo, uma madeira teria aptidão para ser uma mesa, ela é potencialmente uma mesa, mas não necessariamente ela seja uma matéria para a produção de tal ente, há possibilidade de que seja escolhida para tal finalidade e assim se transforme em uma mesa. Matéria é potência e forma, na medida em que é atualidade. Em suma, um ente só tem a potencialidade de se tornar um ato, quando a forma proporciona a determinação à matéria. Destaca-se que potencialidade é subsistente ao ato. (cf. BRANCO, 2018, p. 143).

No entanto, para Aristóteles, há três tipos de entes para os quais há três tipos de saberes respectivos. Há os entes naturais que possuem o princípio de sua mobilidade em si mesmos. Há os entes técnicos, os quais sua mobilidade depende da interferência da produção humana, conforme o exemplo da madeira. E o ente desprovido de mobilidade, portanto imóvel, que dá suporte à mobilidade de todos os outros entes. Este ente fora tradicionalmente chamado de primeiro motor imóvel, e é denominado pelo filósofo como o divino. Nesse sentido, a sabedoria 
teórica é considerada neste pensamento como a forma mais elevada de vida para o homem, pois é ela que coloca o homem em contato com o ente propriamente supremo, com o divino. Ainda que a sabedoria prática seja amplamente discutida por Aristóteles, ela é colocada em uma posição de segunda ordem, hierarquicamente menor que a sabedoria teórica, uma vez que está associada a entes móveis, que se alteram incessantemente (cf. CASANOVA, 2015, p. 91).

A formulação aristotélica do primeiro motor imóvel, como a causa primeira dos entes em geral, que é, essencialmente, causa de si próprio, indica aqui a perpetuação mesmo da formulação da questão acerca do sentido do ser que, iniciada na filosofia socrático-platônico, permanece, ainda que sob as nuanças e novas determinações próprias da filosofia aristotélica. Evidencia-se o horizonte interpretativo sedimentado que possibilitara as concepções seguintes acerca do ente homem e seu ser.

O conceito grego de ser enquanto a permanência constante junto ao que é sempre, consiste segundo Casanova, num problema ao se considerar o caráter de mortal do ente homem. Uma vez que, a mortalidade do homem, sua finitude propriamente, inviabiliza uma unificação plena com o verdadeiramente ente, pensado aqui como causa primeira, o mundo das ideias, ou conforme Aristóteles: o divino. Isso, pois, não há como esperar que o homem se mantenha incessantemente em ligação com aquilo que é sempre, isto é, não perece, é imutável, tendo em vista que o homem não possui essa mesma natureza, pois é, necessariamente finito.

Apenas os pensadores primordiais puderam pensar a physis como a predominância do desabrochar que nesse presentar-se vem a ser, mas que igualmente permanece em inclinação para o ausentar-se ou esconder-se, ocultação. O velar deste caráter do que se ausente é o que possibilitou propriamente o surgimento do lógos metafísico. Isto é, se nos pensadores originários lógos fora pensado como o enunciado de algo que ia ao encontro mesmo daquilo que ao enunciar se enunciava, o lógos metafísico, enquanto discurso na filosofia platônicaaristotélica, se constitui enquanto um enunciando sobre algo, isto quer dizer que algo subjaz ao que é enunciado.

É neste sentido que, conforme Casanova, na lógica e na gramática as proposições do que é enunciado são tidos como se tivesse consistência própria e independente do horizonte vivencial no qual tal discurso fora inicialmente constituído. Em suma, verdade deixa de ser uma determinação ontológica do ser- 
aí, para se mostrar como uma propriedade ôntica dos entes dos quais os discursos se estratificam. Sendo, portanto, tal horizonte interpretativo que possibilita que o ente homem e os entes que se relacionem a este sejam tematizados de diversas formas e classificados, ou conceituados, compondo assim sistemas de conhecimento acerca do ente homem. Sendo assim, há duas teses que devem ser memoradas para o desenvolvimento posterior deste estudo: a tese de que ontologia grega se constitui a partir de uma decisão ontológica de estabelecer o ser como presença constante; e a tese de que tal decisão permaneceu impensada no interior de toda a história da filosofia e do pensamento ocidental, propriamente.

Enfim, poder-se-ia concluir que Heidegger endereça uma crítica contundente a história da filosofia ocidental e, mais precisamente, à metafísica, explanando como ela perpassa as obras dos pensadores considerados primordiais. Ocorre que, ao debruçar sobre o problema ontológico, seu achado mostrou que, não obstante o esforço intelectual anterior, a sedimentação de teorias serviu para aquilo que ele alcunha de esquecimento do ser. Heidegger tem um jeito peculiar na forma de discorrer a respeito da ontologia e, para fazê-lo, executa correções no modus operandi da filosofia precedente, a fim de operar com propriedade.

\section{Referências}

BRANCO, R. A. C. Do esquecimento do ser à serenidade: o pensamento entre o primeiro princípio e o outro princípio em Heidegger. Dissertação (Mestrado) Instituto de Ciências Humanas Departamento de Filosofia, Universidade de Brasília, Brasília, 2018.

CABRAL, A. M. Nietzsche e a semântica da vontade de poder. Rev. Trágica: Estudos sobre Nietzsche, Rio de Janeiro, v. 2, n. 1, p. 20- 37, 2009.

CABRAL, A. M. Niilismo e hierofania: uma abordagem a partir do confronto entre Nietzsche e Heidegger. Tese (Doutorado) - Centro de Ciências Sociais Instituto de Filosofia e Ciências Humanas, Universidade do Estado do Rio de Janeiro, Rio de Janeiro, 2011.

CASANOVA, M. A. Compreender Heidegger. $5^{\text {a }}$ ed. Rio de Janeiro: Vozes, 2015.

CASANOVA, M. A. Mundo e historicidade: leituras fenomenológicas de ser e tempo. Rio de Janeiro: Via Verita, 2017.

CASANOVA, M. A. O homem entediado: niilismo e técnica no pensamento de Martin Heidegger. Ekstasis: Rev. de hermenêutica e fenomenologia, Rio de Janeiro, v. 1, n. 1, p. 184-224, 2012. 
CHAUÍ, M. Introdução à história da filosofia: dos Pré-socráticos a Aristóteles. $2^{\mathrm{a}}$ ed. São Paulo: Companhia das Letras, 2002.

FEREZ, O. C. Vida e obra. In: NIETZSCHE, F. Obras Incompletas. Seleção de texto de Gérard Lebrun. Tradução e notas de Rubens Rodrigues Torres Filho. Botucatu: Nova Cultural, 1996.

FERREIRA, G. P. A questão do ser em M. Heidegger vista a partir do texto "A sentença de Anaximandro". Rev. Existência e Arte, São João Del Rei, v. 2, n. 2, p. 17, dez. 2006.

HADOT, P. O que é a filosofia antiga? Tradução de Dion Davi Macedo. $6^{\mathrm{a}}$ ed. São Paulo: Edições Loyola, 2014.

HEIDEGGER, M. Carta sobre o humanismo. Tradução de Rubens Eduardo Frias. $2^{\mathrm{a}}$ ed. São Paulo: Centauro, 2005.

HEIDEGGER, M. Introdução à filosofia. Tradução de Marco Antonio Casanova. $2^{\mathrm{a}}$ ed. São Paulo: Martins Fontes, 2009.

HEIDEGGER, M. Ser e tempo. Tradução de Marcia Sá Cavalcante Schuback. $10^{\mathrm{a}}$ ed. Rio de Janeiro: Vozes, 2015.

LOPARIC, Z. Martin Heidegger, 2014: Contribuições à Filosofia. (Do acontecimento apropriador). Tradução Marco Casanova. Rio de Janeiro: Via Vérita, 504p. Natureza Humana, São Paulo, v. 17, n. 1, p. 127-134, 2015.

LYRA, E. Heidegger, história e alteridade: Sobre a essência da verdade como ponto de partida. Natureza Humana, São Paulo, v. 8, n. 2, p. 337-356, dez. 2006.

NIETZSCHE, F. W. A gaia ciência. Tradução de Paulo César de Souza. São Paulo: Companhia das Letras, 2001.

NIETZSCHE, F. W. Crepúsculo dos ídolos. Tradução de Paulo César de Souza. São Paulo: Companhia das Letras, 2006.

STÖRIG, H. J. História Geral da Filosofia. $2^{\text {a }}$ ed. Rio de Janeiro: Vozes, 2009.

Recebido em: 20/04/2020. Aprovado em: 31/10/2020. Publicado em: 03/11/2020. 